\title{
EFFECTS OF PROSTAGLANDINS, CYCLIC AMP, SEMINAL PLASMA, INDOMETHACIN, AND OTHER FACTORS ON OVIPOSITION IN THE JAPANESE QUAIL, COTURNIX COTURNIX JAPONICA
}

\author{
F. HERTELENDY \\ Departments of Internal Medicine and Physiology, \\ St Louis University School of Medicine, St Louis, Missouri 63104, U.S.A.
}

(Received 13th November 1973)

\begin{abstract}
Summary. Premature oviposition was induced in the coturnix quail by intrauterine injection of prostaglandins, essential fatty acids, dibutyryl cyclic AMP, and human seminal plasma. Aspirin and indomethacin inhibited the response to prostaglandin precursors but not to $\mathrm{PGE}_{1}$. Theophylline potentiated the effect of dibutyryl cyclic AMP and low doses of $\mathrm{PGE}_{1}$ and $\mathrm{PGE}_{2}$. Fowl, turkey, bull, boar, and stallion seminal plasma was ineffective on oviposition and contained only small amounts of prostaglandins as determined by radioimmunoassay. It is suggested that prostaglandins may have a physiological rôle in the regulation of oviposition.
\end{abstract}

\section{INTRODUCTION}

Although a variety of substances can stimulate the avian uterus to contract and expel its content, the physiological control of oviposition, like that of parturition, is still largely unknown. The possible mechanisms which may be involved in oviposition have been reviewed by Gilbert (1971). Release of vasotocin, the potent natural avian oxytocic hormone, appears to be associated with the promotion of oviposition. Recent studies from this laboratory suggested that prostaglandins, particularly $\mathrm{PGE}_{1}$, may act as physiological mediators of oviposition (Hertelendy, 1972, 1973; Hertelendy, Yeh \& Biellier, 1974). In this study, the effects of prostaglandins, precursor fatty acids, inhibitors of prostaglandin synthesis, avian and mammalian seminal plasma, exogenous cyclic AMP, and theophylline on oviposition have been examined.

\section{MATERIALS AND METHODS}

Birds

Japanese quail (Coturnix coturnix japonica), 6 to 12 months old, were housed singly in a temperature- $\left(22 \pm 1^{\circ} \mathrm{C}\right)$ and light-controlled (lights on 06.00 to 22.00 hours) room and had free access to Purina Game Bird Chow and water. Under these conditions, birds usually lay between 14.00 and 18.00 hours. 
A record of egg laying was kept for several weeks before and during the experiments. All experiments were carried out between 09.00 and 11.00 hours.

The coturnix quail egg spends 19 to $20 \mathrm{hr}$ in the uterus and since a superficial layer of pigments is deposited on the shell about $3 \frac{1}{2} \mathrm{hr}$ before oviposition (Woodard \& Mather, 1964), the premature expulsion of an egg can be readily detected. All test compounds were given directly into the uterus (Hertelendy, 1972) in a volume of $0.1 \mathrm{ml}$.

\section{Drugs and other materials}

Dibutyryl cyclic AMP (Calbiochem), indomethacin (Merck, Sharp \& Dohme), aspirin (acetyl salicylate, Sigma) and theophylline (Mallinckrodt) were dissolved in saline and diluted to required concentrations. Fatty acids (minimum purity $99 \%$ ) were obtained from the Sigma Chemical Company and were diluted with propylene glycol: $\mathrm{H}_{2} \mathrm{O}(1: 1)$. The seminal plasma from boar, stallion, and bull represented single ejaculates while the specimens from fowl

Table 1. Induction of oviposition in coturnix quail by prostaglandins

\begin{tabular}{l|c|c|c|c}
\hline Compound & $\begin{array}{c}\text { Dose } \\
(\mu g)\end{array}$ & $\begin{array}{c}\text { No. of } \\
\text { tests }\end{array}$ & $\begin{array}{c}\text { Successful } \\
\text { inductions }\end{array}$ & $\begin{array}{c}\text { Average induction } \\
\text { time (min) }\end{array}$ \\
\cline { 1 - 4 } PGE $_{1}$ & 0.01 & 7 & 5 & $3 \cdot 8$ \\
PGE $_{2}$ & $0 \cdot 10$ & 9 & 5 & $2 \cdot 0$ \\
PGF $_{2 \alpha}$ & 1.0 & 9 & 7 & 21.5 \\
PGA $_{1}$ & 10.0 & 10 & 7 & $10 \cdot 4$ \\
PGF $_{1 \beta}$ & 10.0 & 10 & 7 & 4.0 \\
PGF $_{2 \beta}$ & 10.0 & 7 & 5 & 3.2 \\
\hline
\end{tabular}

(White Leghorn) and turkeys (bronze) were pooled from ten to fifteen birds. The human seminal plasma was pooled from three young healthy donors. Stock solutions of prostaglandins (Upjohn) were prepared in $95 \%$ ethanol at concentrations of 1 to $5 \mathrm{mg} / \mathrm{ml}$. Small volumes of these solutions were freshly diluted with saline. Concentrations of prostaglandins $\mathrm{E}, \mathrm{F}$ and $\mathrm{A}$ in the seminal plasma were determined by radioimmunoassay (Jaffe, Behrman \& Parker 1973). This procedure involved organic solvent extraction, followed by chromatographic separation of the three major groups of prostaglandins on silicic acid and radioimmunoassay using antisera raised in goats and rabbits against $\mathrm{PGE}_{1}$ and $\mathrm{PGF}_{2 \alpha}$ and $\mathrm{PGA}_{1}$ conjugated to BSA. Separation of bound and free prostaglandins was carried out using dextran-coated charcoal.

\section{RESULTS}

\section{Effect of prostaglandins}

The most potent prostaglandin tested was $\mathrm{PGE}_{1}$. As little as $10 \mathrm{ng}$ induced premature oviposition in five out of seven birds with an average time of $3.8 \mathrm{~min}$ (Table 1). The PGF ${ }_{2 \alpha}$ was approximately 100 -fold less effective than the $\mathrm{PGE}_{1}$ and about one order of magnitude less potent than the $\mathrm{PGE}_{2}$. In addition, the mean induction time after $\mathbf{P G F}_{2 \alpha}$ administration was significantly more 
prolonged (21.5 min versus 3.8 and 2.0 for $\mathrm{PGE}_{1}$ and $\mathrm{PGE}_{2}$, respectively). A further tenfold decrease in potency was observed with $\mathrm{PGA}_{1}, \mathrm{PGF}_{1 \beta}$ and $\mathrm{PGF}_{2 \beta}$.

Effects of precursor fatty acids, aspirin, and indomethacin

Between 5 and $0.05 \mu \mathrm{l}$ arachidonic acid, a precursor of $\mathrm{PGE}_{2}$ and $\mathrm{PGF}_{2 \alpha}$, produced a $100 \%$ success rate in the induction of premature oviposition and as

Table 2. Effects of unsaturated fatty acids, aspirin, and indomethacin on oviposition in the coturnix quail

\begin{tabular}{|c|c|c|c|c|}
\hline Compound & Dose & $\begin{array}{c}\text { No. of } \\
\text { tests }\end{array}$ & $\begin{array}{c}\text { No. of } \\
\text { ovipositions }\end{array}$ & $\begin{array}{l}\text { Average induction } \\
\text { time (min) }\end{array}$ \\
\hline Arachidonic acid & $\begin{array}{l}5 \cdot 0 \mu \mathrm{l} \\
1 \cdot 0 \mu \mathrm{l} \\
0 \cdot 1 \mu \mathrm{l} \\
0 \cdot 05 \mu \mathrm{l} \\
0.01 \mu \mathrm{l}\end{array}$ & $\begin{array}{r}4 \\
5 \\
8 \\
3 \\
17\end{array}$ & $\begin{array}{r}4 \\
5 \\
8 \\
3 \\
12\end{array}$ & $\begin{array}{r}11 \cdot 7 \\
13 \cdot 8 \\
3 \cdot 5 \\
3 \cdot 7 \\
8 \cdot 2\end{array}$ \\
\hline Linoleic acid & $\begin{array}{l}5 \cdot 0 \mu \mathrm{l} \\
1 \cdot 0 \mu \mathrm{l}\end{array}$ & $\begin{array}{l}13 \\
10\end{array}$ & $\begin{array}{r}12 \\
4\end{array}$ & $\begin{array}{l}23 \cdot 5 \\
26 \cdot 0\end{array}$ \\
\hline Aspirin + linoleic acid & $\begin{array}{l}5 \mathrm{mg} \\
5 \mu \mathrm{l}\end{array}$ & 10 & 1 & 34 \\
\hline Indomethacin + arachidonic acid & $\begin{array}{l}0.1 \mathrm{mg} \\
0 \cdot 1 \quad \mu \mathrm{l}\end{array}$ & 10 & 1 & $10 \cdot 5$ \\
\hline Indomethacin $+\mathrm{PGE}_{1}$ & $\begin{array}{l}1.0 \mathrm{mg} \\
0.025 \mu \mathrm{g}\end{array}$ & 5 & 5 & $4 \cdot 8$ \\
\hline Propylene-glycol & $0.1 \mathrm{ml}$ & 8 & 0 & - \\
\hline
\end{tabular}

Table 3. Effect of avian and mammalian seminal plasma on oviposition in the coturnix quail

\begin{tabular}{l|l|c|c|c}
\hline Species & $\begin{array}{c}\text { Volume } \\
(\mathrm{ml})\end{array}$ & $\begin{array}{c}\text { No. of } \\
\text { tests }\end{array}$ & $\begin{array}{c}\text { No. of } \\
\text { ovipositions }\end{array}$ & $\begin{array}{c}\text { Average induction } \\
\text { time (min) }\end{array}$ \\
\cline { 2 - 4 } Fowl & $0 \cdot 1$ & 8 & 1 & $15 \cdot 0$ \\
& $0 \cdot 05$ & 7 & 0 & $6 \cdot 0$ \\
Turkey & $0 \cdot 02$ & 9 & 0 & - \\
Bull & $0 \cdot 1$ & 6 & 1 & 22 \\
& $0 \cdot 1$ & 6 & 0 & - \\
Boar & $0 \cdot 05$ & 2 & 0 & - \\
& $0 \cdot 1$ & 5 & 0 & - \\
Stallion & $0 \cdot 05$ & 3 & 0 & - \\
Human & $0 \cdot 2$ & 6 & 2 & $5 \cdot 5$ \\
& $0 \cdot 1$ & 7 & 1 & $4 \cdot 0$ \\
& $0 \cdot 1$ & 6 & 6 & $6 \cdot 3$ \\
& $0 \cdot 05$ & 5 & 5 & 3.0 \\
& $0 \cdot 025$ & 8 & 6 & $2 \cdot 3$ \\
& $0 \cdot 01$ & 8 & 3 & 3.0 \\
\hline
\end{tabular}

little as $0.01 \mu \mathrm{l}$ (or approximately $10 \mu \mathrm{g}$ ) induced egg laying in seven out of twelve birds. The shortest induction time (interval between injection and oviposition) was observed at dosages of 0.05 and $0 \cdot 1 \mu \mathrm{l} /$ bird (Table 2). Above these levels, side effects similar to those found with high levels of prostaglandins (Hertelendy, 1972) were observed. Assuming that arachidonic acid gave rise 
to $\mathrm{PGE}_{2}$ and $\mathrm{PGF}_{2 \alpha}$ in equal proportion and that oviposition was due to this rise in prostaglandins in the uterine tissue, only a small percentage of the precursor was converted to the active compound since $0 \cdot 1 \mu \mathrm{g} \mathrm{PGE}_{2}$ or $1 \mu \mathrm{g}$ $\mathrm{PGF}_{2 \alpha}$ yielded a response similar to that of $10 \mu \mathrm{g}$ arachidonic acid. Linoleic acid, which must undergo elongation and desaturation before conversion to prostaglandins, was about two orders of magnitude less effective than arachidonic acid. Aspirin $(5 \mathrm{mg})$ and indomethacin $(0.1 \mathrm{mg})$ blocked the effects of linoleic and arachidonic acids, respectively, but indomethacin had no effect on PGE $_{1}$-induced oviposition. Propylene glycol which served as the diluent was without effect.

Table 4. Prostaglandin content of avian and mammalian seminal plasma as determined by radioimmunoassay

\begin{tabular}{l|c|c|c}
\hline \multicolumn{1}{c|}{ Species } & $P G E(n g / m l)$ & $P G F(n g / m l)$ & $P G A(n g / m l)$ \\
\hline Human & 123.7 & 456.4 & 133.4 \\
Stallion & 6.4 & 1.4 & 1.6 \\
Boar & 0.5 & 0.2 & 0.2 \\
Bull & 0.4 & 0.5 & 0.2 \\
Fowl & 0.2 & $<0.1$ & $<0.1$ \\
Turkey & 0.3 & - & - \\
\hline
\end{tabular}

Table 5. Effects of dibutyryl cyclic AMP (DB-cAMP), and theophylline on oviposition in the coturnix quail

\begin{tabular}{|c|c|c|c|c|}
\hline Compound & $\begin{array}{l}\text { Dose } \\
(\mu g)\end{array}$ & $\begin{array}{l}\text { No. of } \\
\text { quail }\end{array}$ & $\begin{array}{c}\text { No. of } \\
\text { ovipositions }\end{array}$ & $\begin{array}{l}\text { Average induction } \\
\text { time (min) }\end{array}$ \\
\hline DB-cAMP & 50 & 13 & 7 & $5 \cdot 1$ \\
\hline $\begin{array}{l}\text { DB-cAMP } \\
\text { + theophylline }\end{array}$ & $\begin{array}{l}50 \\
50\end{array}$ & 9 & 8 & $5 \cdot 9$ \\
\hline Theophylline & 50 & 6 & 0 & - \\
\hline $\mathrm{PGE}_{1}$ & 0.001 & 6 & 1 & $4 \cdot 0$ \\
\hline $\begin{array}{l}\mathrm{PGE}_{1} \\
\quad+\text { theophylline }\end{array}$ & $0^{0.001}$ & 6 & 5 & $2 \cdot 4$ \\
\hline $\mathrm{PGE}_{2}$ & 0.01 & 8 & 2 & $5 \cdot 5$ \\
\hline $\begin{array}{l}\mathrm{PGE}_{2} \\
\quad+\text { theophylline }\end{array}$ & $\begin{array}{l}0 \cdot 01 \\
50\end{array}$ & 5 & 5 & $2 \cdot 0$ \\
\hline
\end{tabular}

Effect of seminal plasma

With the exception of human seminal plasma which contains large amounts of prostaglandins, that of the other species including the fowl and turkey did not consistently induce oviposition (Table 3 ). Subsequent analysis of the semen by radioimmunoassay demonstrated that only the human seminal fluid contained appreciable amounts of all three groups of prostaglandins (Table 4).

\section{Effect of cyclic AMP and theophylline}

Intrauterine injection of dibutyryl cyclic AMP at a level of $50 \mu \mathrm{g} / \mathrm{bird}$ induced premature oviposition in seven out of thirteen birds (54\%). Simultaneous administration of theophylline (50 $\mu \mathrm{g} / \mathrm{bird})$ increased the success rate to eight 
out of nine $(90 \%)$, while theophylline alone had no effect (Table 5). Similarly, theophylline potentiated the effect of sub-optimal doses of $\mathrm{PGE}_{1}(1 \mathrm{ng})$ and $\mathrm{PGE}_{2}$ (10 ng).

\section{DISCUSSION}

One of the main functions of the avian uterus, as of the mammalian uterus, is the expulsion of its content, but the avian uterus differs in that it performs the act of oviposition almost daily. The present studies and those reported elsewhere (Hertelendy, 1972; Hertelendy et al., 1974) show that the avian uterus is highly sensitive to prostaglandins and may serve as an exceptionally useful model for studies on the rôle of prostaglandins in the initiation and promotion of 'labour'. Recent evidence indicates that prostaglandins may be involved in parturition as well as in oviposition since indomethacin effectively blocks the induction of labour by oxytocin in pregnant rabbits at term and oviposition in the coturnix quail (Hertelendy, 1973). The present studies also demonstrate that two essential fatty acids which have been shown to serve as precursors of $\mathrm{PGE}_{2}$ and $\mathrm{PGF}_{2 \alpha}$ (Van Dorp, Beerthuis, Nugteren \& Von Keman, 1964; Bergström, Danielson, Klenberg \& Samuelsson, 1964) can induce oviposition indicating the presence of prostaglandin synthetase in the avian uterus. This interpretation is consistent with the studies of Christ \& Van Dorp (1972) who found prostaglandin synthetase (as measured by the conversion of dihomo- $\gamma$ linoleic acid to $\mathrm{PGE}_{1}$ ) in the hen oviduct and with the demonstration in the present experiments that aspirin and indomethacin blocked the response to linoleic and arachidonic acids. The possibility, however, that aspirin-like drugs, by virtue of their interference with calcium flux (Northover, 1972, 1973), act as smooth muscle relaxants independently of their action on prostaglandin synthesis and that polyunsaturated fatty acids initiate oviposition by a mechanism other than accelerating prostaglandin production (e.g. a detergent-like effect; Davies \& Rideal, 1963) cannot be ruled out. Studies are in progress to examine this possibility.

High concentrations of prostaglandins occur in human and sheep seminal fluid (Bygdeman \& Holmberg, 1966; Hamberg \& Samuelsson, 1966). The semen of several other species such as the rabbit (Horton \& Thompson, 1964), goat (Eliasson, 1959) and monkey (Bergström, Carlson \& Weeks, 1968) also contains appreciable amounts of prostaglandins, but bull, boar and stallion seminal fluid was inactive in the bioassay of Eliasson (1959). Although PGE, PGF and PGA have been detected in all mammalian specimens of the present study using a sensitive radioimmunoassay procedure which can measure as little as $15 \mathrm{pg}$ of each of the three main groups of prostaglandins, these levels were much lower than the concentration found in human semen. The ready induction of oviposition by human semen and the relative ineffectiveness of bull, boar, and stallion seminal fluid may, therefore, be attributed to their respective prostaglandin content.

Apart from a single published estimate (Christ \& Van Dorp, 1972), there is no information about the prostaglandin content of avian semen. These investigators analysed two samples of fowl semen and found $\mathrm{PGE}_{1}$ and $\mathrm{A}$ ("maximal 
amounts about $20 \mu \mathrm{g} / \mathrm{ml}$ each") and only trace amounts of PGF. Both the response in vivo of the coturnix quail and the analytical data of the present studies indicate that the prostaglandin content of the fowl and turkey seminal plasma is, in fact, much lower than the above estimate. Only PGE was present in detectable amounts.

In view of the reported anti-oxytocic effect of cyclic AMP on smooth muscle (Andersson, 1972), the induction of premature oviposition by this cyclic nucleotide and the potentiation of its effect and that of low doses of PGE $_{1}$ and $\mathrm{PGE}_{2}$ by theophylline was rather unexpected. The effect of epinephrine and some other drugs that cause smooth muscle relaxation has been attributed to their stimulant effect on adenyl cyclase or inhibition of cyclic AMP phosphodiesterase both of which lead to the accumulation of intracellular cyclic AMP (Robison, Butcher \& Sutherland, 1971). Published evidence, however, indicates that the inhibition by epinephrine of smooth muscle contraction may be independent of its elevation of cyclic AMP levels (Polacek \& Daniel, 1971). This view is supported by the observations of Harbon \& Clauser (1971) who found that in addition to epinephrine, $\mathrm{PGE}_{1}$ and $\mathrm{PGE}_{2}$ greatly stimulated adenyl cyclase in rat myometrium, while $\mathrm{PGF}_{2 \alpha}$ was without effect. In the myometrium of pregnant monkeys, epinephrine as well as oxytocin stimulated adenyl cyclase activity (Beatty, Bocek \& Young, 1973). On the other hand, Bhalla, Sanborn \& Korenman, (1972) reported that oxytocin, $\mathrm{PGE}_{\mathbf{1}}$ and $\mathrm{PGF}_{2 \alpha}$ inhibited isoproterenol-induced accumulation in vitro of cyclic AMP in the uteri of oophorectomized rats whereas $\mathrm{PGE}_{2}$ exhibited a dose-related stimulant effect which was not blocked by oxytocin. There also appears to be a reciprocal relationship, however, in the stimulation of prostaglandin release by cyclic AMP. Addition of dibutyryl cyclic AMP to the medium caused an increase in PGE production by certain lines of tumour cells (Hamprecht, Jaffe \& Philpott, 1973) and by mouse ovaries and rat testicular slices (Kuehl, Cirillo, Ham \& Humes, 1972). Kuehl et al. have also observed that fluoroindomethacin blocked the cyclic AMP-stimulated synthesis of prostaglandin. Furthermore, a marked stimulation of phospholipase A activity by cyclic AMP and an enhancement of this effect by theophylline in rat lung tissue has also been reported (Imre, 1972). The results of the present study and the observation that phospholipase $A$ is a potent inducer of oviposition in the coturnix quail (Hertelendy, 1972) suggest that the effect of cyclic AMP and theophylline might be mediated by increased production of prostaglandin within the uterine cells, possibly as a result of activation of phospholipase $\mathrm{A}$.

\section{ACKNOWLEDGMENTS}

I am indebted to Dr A. Kenny, Dalton Research Center, University of Missouri, for generously supplying the coturnix, Dr H. Biellier and Dr B. Day, University of Missouri, Columbia, for the seminal plasma specimens, Dr H. Behrman, Merck Institute, Rahway, for antiserum to $\mathrm{PGF}_{2 \alpha}$ and $\mathrm{Dr} \mathrm{J}$. Pike, The Upjohn Co., for the prostaglandins. 


\section{REFERENCES}

Andersson, R. G. G. (1972) Gyclic AMP and calcium ions in mechanical and metabolic responses of smooth muscles; influence of some hormones and drugs. Acta physiol. scand., Suppl. 382.

Beatty, C. H., Bocek, R. M. \& Young, M. K. (1973) Effect of oxytocin and epinephrine on the adenylate cyclase activity of myometrium from pregnant rhesus monkeys. Horm. Metab. Res. 5, 213.

Bergström, S., Garlson, L. A. \& Weeks, J. R. (1968) The prostaglandins: a family of biologically active lipids. Pharmac. Rev. 20, 1.

Bergström, S., Danielson, H., Klenneerg, D. \& Samuelsson, B. (1964) The enzymatic conversion of essential fatty acids into prostaglandins. F. biol. Chem. 239, PC4006.

Bhalla, R. C., Sanborn, B. M. \& Korenman, S. G. (1972) Hormonal interactions in the uterus: inhibition of isoproterenol-induced accumulation of adenosine $3^{\prime}, 5^{\prime}$-cyclic monophosphate by oxytocin and prostaglandins. Proc. natn. Acad. Sci. U.S.A. 69, 3761.

Bygdeman, M. \& Holmberg, O. (1966) Isolation and identification of prostaglandins from rat seminal plasma. Acta chem. scand. 20, 2308.

Christ, E. J. \& VAN Dorp, D. A. (1972) Comparative aspects of prostaglandin biosynthesis in animal tissues. Biochim. biophys. Acta, 270, 537.

Davies, J. T. \& Rideal, E. K. (1963) Interfacial Phenomena. Academic Press, New York.

Eliasson, R. (1959) Studies on prostaglandin occurrence, formation and biological actions. Acta physiol. scand. 46, Suppl. 158, 1.

GiLberT, A. B. (1971) Transport of the egg through the oviduct and oviposition. In Physiology and Biochemistry of the Domestic Fowl, Vol. 3, p. 1345. Eds. D. J. Bell and B. M. Freeman. Academic Press, London and New York.

Hamberg, M. \& Samuelsson, B. (1966) Prostaglandins in human seminal plasma. J. biol. Chem. 241, 257.

Hamprecht, B., Jaffe, B. M. \& Philpotr, G. W. (1973) Prostaglandin production by neuroblastoma, glioma and fibroblast cell lines; stimulation by $\mathrm{N}^{6}, \mathrm{O}^{2}$-dibutyryl adenosine $3^{\prime}: 5^{\prime}$-cyclic monophosphate. FEBS Letters, 36, 193.

Harbon, S. \& Clauser, H. (1971) Cyclic adenosine 3',5'-monophosphate levels in rat myometrium under the influence of epinephrine, prostaglandins and oxytocin. Correlations with uterus motility. Biochem. biophys. Res. Commun. 44, 1496.

Hertelendy, F. (1972) Prostaglandin-induced premature oviposition in the coturnix quail. Prostaglandins, 2, 269.

Hertelendy, F. (1973) Block of oxytocin-induced parturition and oviposition by prostaglandin inhibitors. Life Sci. 13, 1581.

Hertelendy, F., Yeh, M. \& Brellier, H. (1974) Induction of oviposition in the domestic hen by prostaglandins. Gen. $\&$ compar. Endocr. 22, 529.

Horton, E. W. \& THOMPson, C. J. (1964) Thin-layer chromatography and bioassay of prostaglandins in extracts of semen and tissues of the male reproductive tract. Br. J. Pharmac. 22, 183.

IMRE, S. (1972) The effect of cAMP on phospholipid metabolism. Acta biochim. biophys. acad. sci. hung. $7,247$.

Jaffe, B. M., Behrman, H. R. \& Parker, C. W. (1973) Radioimmunoassay measurement of prostaglandins $\mathrm{E}, \mathrm{A}$, and $\mathrm{F}$ in human plasma. 7. clin. Invest. 52, 398.

Kuehl, F. A., Girillo, V. J., Ham, E. A. \& Humes, J. L. (1972) The regulatory role of the prostaglandins on the cyclic $3^{\prime}, 5^{\prime}$-AMP system. Adv. Biosci. 9, 155.

Northover, B. J. (1972) The effects of indomethacin on calcium, sodium, potassium and magnesium fluxes in various tissues of the guinea-pig. Br. J. Pharmac. Chemother. 45, 651.

NoRTHover, B. J. (1973) Effect of anti-inflammatory drugs on the binding of calcium to cellular membranes in various human and guinea-pig tissues. Br. 7. Pharmac. Chemother. 48, 496.

Polacek, I. \& Daniel, E. E. (1971) Effect of $\alpha$ - and $\beta$-adrenergic stimulation on the uterine motility

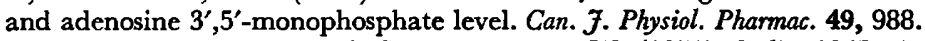

Robison, A. G., Butcher, R. W. \& Sutheri.And, E. W. (1971) Cyclic AMP. Academic Press, New York.

Van Dorp, D. A., Beerthuis, R. K., Nugteren, D. H. \& Von Keman, H. (1964) Enzymatic conversion of all cis-polyunsaturated fatty acids into prostaglandins. Nature, Lond. 203, 839.

WoodARD, A. E. \& MATHER, I. V. (1964) The timing of ovulation, movement of the ovum through the oviduct, pigmentation and shell deposition in Japanese quail (Coturnix cotumix japonica). Poult. Sci. 43,1472 . 